\author{
MIECZYSŁAW C. PACZKOWSKI OFM ${ }^{1}$ \\ Uniwersytet Mikołaja Kopernika w Toruniu \\ ORCID 0000-0002-4045-2314
}

\title{
OBECNOŚĆ FRANCISZKAŃSKA W EGIPCIE (XIII-XVIII W.)
}

\section{Franciscan Presence in Egypt $\left(13^{\text {th }}-18^{\text {th }}\right.$ Centuries $)$ \\ Abstract}

Since its inception, the Franciscan Order not only had guarded sacred sites in the Holy Land but also conducted missionary activity in the territories occupied by Muslims. The article presents the main lines of the activity of the Franciscan missionaries in the $13^{\text {th }}$ and $18^{\text {th }}$ centuries. Initially, the Friars limited themselves to the pastoral care of Europeans. During this period there was a continuous and uninterrupted effort to maintain the Christian faith among the population, to develop charitable institutions, and to establish the institutional structure of the Catholic Church.

Keywords: Egypt, Franciscan Order, missions (history), Copts, Catholic Church

\begin{abstract}
Abstrakt
Od chwili powstania zakon franciszkański nie tylko strzegł sanktuariów w Ziemi Świętej, ale także prowadził działalność misyjną na terytoriach opanowanych przez islam. Artykuł przedstawia główne linie działalności franciszkańskich misjonarzy w okresie XIII-XVIII w. Początkowo bracia mniejsi ograniczali się do prowadzenia działalności duszpasterskiej wśród Europejczyków. Starano się w sposób stały i ciągły utrzymać wiarę chrześcijańską wśród egipskiej ludności, rozwijać dzieła charytatywne i ustanowić instytucjonalne struktury Kościoła katolickiego.
\end{abstract}

Słowa kluczowe: Egipt, franciszkanie (zakon), misje (historia), koptowie, Kościół katolicki

E gipt kojarzy się najczęściej z pozostałościami starożytnej cywilizacji faraonów i z atrakcjami turystycznymi. Obecnie to kraj muzułmański, ale zauważa się silną mniejszość

\footnotetext{
1 Zatrudniony w Katedrze Teologii Historycznej WT UMK w Toruniu. Publikuje prace z zakresu patrologii, historii egzegezy (okres patrystyczny), teologii i historii chrześcijańskiego Wschodu oraz palestynologii. Wykładał w Jerozolimie, Rzymie oraz w Polsce. Przewodnik grup pielgrzymkowych po Bliskim Wschodzie. Współpracuje z Fundacją Komisariat Ziemi Świętej w Polsce. E-mail: celestyn@umk.pl.
} 
chrześcijan - Koptów ${ }^{2}$. Nad Nilem nie brak śladów franciszkańskich ${ }^{3}$. Obecność braci mniejszych w Egipcie jest szczególnie znacząca ${ }^{4}$, bo wiąże się z pobytem ich Założyciela św. Franciszka z Asyżu w tamtym rejonie świata i jego wolą pozostawienia tam braci. W zmiennych warunkach historycznych i społecznych XIII-XVIII w. minoryci podtrzymywali obecność chrześcijańską i tożsamość katolicką.

\section{Od spotkania do stałej obecności}

O zapale misyjnym św. Franciszka z Asyżu świadczy fakt, że już w pierwszych latach istnienia swego zakonu postanowił on wysłać braci na wszystkie strony świata ${ }^{5}$. Nie chodziło jednak o marzenia i bliżej niesprecyzowane plany. Gdy ustalono dokładny podział terytorialny zakonu na Prowincje ${ }^{6}$, narodziła się od razu „Prowincja Ziemi Świętej” lub „Zamorska”. Obejmowała ona południowo-wschodnie tereny basenu Morza Śródziemnego: od Egiptu aż po Grecję ${ }^{7}$.

Historia obecności franciszkanów w Egipcie rozpoczęła się od spotkania św. Franciszka z Asyżu z sułtanem Malekiem al-Kamalem, wnukiem słynnego Saladyna ${ }^{8}$. Seraficki ojciec udał się do obozu krzyżowców pod Damiettą ${ }^{9}$ To miasto blokowało dostęp to Kairu. Rządzący w Egipcie sułtan Melek-al-Kamal musiał zmagać się z ciągłymi buntami na podległym sobie terytorium. Nie inaczej było po stronie chrześcijańskiej. Podziały w armii krzyżowców były związane nie tylko z chęcią zdobycia jak największych łupów, ale także z kwestiami pojawiających się konfliktów o charakterze narodowym.

\footnotetext{
2 Wspólnota koptyjska stanowi największą mniejszość chrześcijańską na Bliskim Wschodzie. Nominalnie cieszy się wolnością. Jest to jednak jedna z najbardziej prześladowanych wspólnot chrześcijańskich (zob. I. Habib al-Masri, L’Église invincible, „Le Monde Copte”, 9/1980, s. 28-31). Odnośnie do historii Kościoła koptyjskiego por. A. Gerhards, H. Brakmann, Die Koptische Kirche, Stuttgart 1994; W. Myszor, Koptyjski Kościót, w: Encyklopedia Katolicka, t. 9, red. A. Szostek et al., Lublin 2002, kol. 815-823; M.S. Zaki, Histoire des coptes d'Égypte, Paris 2005.

3 Por. F. de Ghyvelde [Janssoone], L'Egypte et les Franciscains. Épisodes de la dernière guerre (documents inédits), s. 1. [Québec] 1897. Autor (franciszkanin) został kanonizowany przez papieża Franciszka w 2016 r.

4 W ujęciu popularyzatorskim zagadnienie zostało przedstawione w: M.C. Paczkowski, Bracia Mniejsi w Egipcie, „Ziemia Święta”, 99/2019, nr 3, s. 36-39; tenże, Franciszkanie nad Nilem, „Ziemia Święta”, 100/2019, nr 4, s. 16-19.

5 Nastąpiło to podczas kapituły generalnej w 1217 r. w Porcjunkuli pod Asyżem.

6 Było ich w sumie jedenaście.

7 To z nią łączy się początek misji franciszkańskiej wśród „niewiernych” (tj. muzułmanów). Rozległa prowincja podczas kapituły generalnej w Pizie (20 maja 1263 r.) została podzielona na obszar prowincji „Romanii”, czyli terytoria zajęte przez krzyżowców, oraz te należące do cesarstwa bizantyjskiego i „prowincję Syrii”. W jej skład, oprócz Palestyny, Syrii i Cypru, weszły także terytoria Egiptu. W literaturze już od początku istnienia tej jednostki terytorialnej zakonu minorytów mówi się o „kustodii”. Określenie pochodzi od łac. custodire (strzec) w nawiązaniu do Iz 62,6. Na temat kustodii por. A. Wiśniowski, Kustodia Ziemi Świętej, w: Encyklopedia Katolicka, t. 10, red. W. Granat et al., Lublin 2004, kol. 272-276 (bibliografia); M.C. Paczkowski, Powstanie i poczatek Kustodii Ziemi Świętej, „Scriptura Sacra”, 13-14/2009- 2010, s. 71-94.

8 Relacja św. Bonawentury mówi, że „sługa Chrystusa, Franciszek... mówił sułtanowi o Trójcy Świętej, o jedynym Bogu i o Zbawicielu wszystkich, Jezusie Chrystusie [...]. Sułtan widząc w mężu Bożym żar i moc ducha, chętnie go słuchał i gorąco prosił, aby pozostał z nim dłużej”; Bonawentura z Bangoregio, Legenda maior IX, 8 , tłum. wg Źródła Franciszkańskie, oprac. R. Prejs, Z.J. Kijas, Kraków 2005.

9 To starożytne Tamiathis (koptyjskie Tamiati), obecnie Dumyat. Por. J. Swastek, Damietta, w: Encyklopedia Katolicka, t. 3, red. F. Gryglewicz et al., Lublin 1979, kol. 990.
} 
Wyróżniało się pośród nich szczególnie stronnictwo powstałe wokół osoby kardynała Pelagiusza z Albano ${ }^{10}$. To właśnie upór z jego strony i odrzucanie kolejnych ofert pokojowych sułtana, znacznie przedłużały oblężenie ${ }^{11}$. Popierali go przedstawiciele zakonów rycerskich oraz włoskich republik morskich. Ci ostatni chcieli z leżącej w delcie Nilu Damietty uczynić wiodące centrum handlowe ${ }^{12}$.

Przypuszcza się, że zamiarem św. Franciszka było przede wszystkim świadczenie o Chrystusie i niesienie pokoju zwaśnionym stronom ${ }^{13}$. Wiele wskazuje na to, że Biedaczyna snuł plany dotyczące obecności swoich braci wśród mieszkańców Bliskiego i Środkowego Wschodu. Jednak w życiu i duchowości św. Franciszka ${ }^{14}$ widać wyraźnie, że czołowe miejsce zajmowała w jego świadomości Ziemia Święta z miejscami zbawienia. Tak było zresztą w przypadku większości średniowiecznych Europejczyków. Ojczyzna Zbawiciela miała znaczenie zarówno symboliczne, jak i konkretne, była celem pielgrzymek, ale również widownią zmagań wojennych o panowanie nad nią ${ }^{15}$ W XIII w. krucjaty militarne zaczęły tracić swój impet i pojawiało się coraz więcej znamion zapowiadających ich porażkę ${ }^{16}$. Biograf Biedaczyny Tomasz z Celano wyraźnie wskazywał na to, że Święty ostrzegał przed tym bardzo wyraźnie ${ }^{17}$.

Zamiar wizyty u sułtana Maleka al-Kamala był niewymownym wyrazem męstwa ${ }^{18}$, bo św. Franciszek powziął tę decyzję nie wtedy, kiedy miało miejsce zawieszenie broni, lecz w pełnym ferworze walki. Po przybyciu na Wschód Biedaczynie z Asyżu udało się spokojnie przejść przez front wojsk krzyżowców oblegających Damiettę i dotrzeć przed sułtana Egiptu. Franciszek, dzięki temu, że był „rozpalony żarliwością swej wiary”, nie bał się wejść w sam środek wrogich wojsk. To zdarzenie tak opisał współczesny Franciszkowi Jakub z Vitry: „Schwytany na drodze przez Saracenów powiedział: «Jestem chrześcijaninem, zaprowadźcie

\footnotetext{
10 Pelagiusz Galvan di Santa Lucia był Portugalczykiem.

11 Sułtan zaproponował w jednej z ofert pokojowych oddanie Jerozolimy, terytoriow palestyńskich i odzyskanie relikwii Krzyża Świętego.

12 Por. A. Elli, Storia della Chiesa copta, t. 2: L'Egitto arabo e musulmano, Cairo-Jerusalem 2003, „Studia Orientalia Christiana Monagraphiae", t. 14, s. 154.

13 Por. A.L. Hoose, Francis of Assisi's way of peace? His conversion and mission to Egypt, „The Catholic Historical Review", 96/2010, nr 3, s. 449-469.

14 Odnośnie do biografii Biedaczyny z Asyżu por. A. House, Święty Franciszek z Asyżu, thum. B. Nawrot, Warszawa 2002.

15 Por. T.V. [T. Verdon], San Francesco e la Terrasanta, w: In Terrasanta. Dalla Crociata alla Custodia dei Luoghi Santi, red. M. Piccirillo, Firenze-Milano 2000, s. 140.

16 Po klęsce krzyżowców w 1187 r. pod Rogami Hittin, armia muzułmańska dowodzona przez Saladyna zdobyła Jerozolimę i wypierała łacinników z terenu Palestyny (por. S. Runciman, Dzieje wypraw krzyżowych, tłum. J. Schwakopf, Warszawa 1987, s. 396-422). Po usunięciu krzyżowców Palestyna pozostawała w rękach muzułmanów, chociaż ostatni bastion chrześcijański - Akko, muzułmanie zdobywają w $1291 \mathrm{r}$. Od tego czasu obecność łacinników w Ziemi Świętej niemal zamiera. Krzyżowcy musieli przenieść się na sąsiednie wyspy, lecz już w 1302 r. została zdobyta wyspa Ruad. Tym samym na Wschodzie nie pozostał już żaden przyczółek chrześcijański. Por. H.J.A. Sire, Kawalerowie Maltańscy, thum. H. Szczerkowska, Warszawa 2000, s. 34-35.

17 „Gdy sługa Chrystusa usłyszał o tym, że chrześcijanie przygotowują się do bitwy, wybuchnął głośnym płaczem i powiedział do swojego towarzysza: «Jeżeli dojdzie do walki - Pan mi to objawił - nie skończy się ona szczęśliwie dla chrześcijan» [...]. Herold Chrystusa wybiegł, przekazał zbawienne upomnienie chrześcijanom, zakazując walki i zapowiadając klęskę. Prawdę uznano za bajkę"; Tomasz z Celano, Vita prima XI, 3.

18 „Franciszek, nieustraszony żołnierz Chrystusa, zdecydował się iść z nadzieją na spełnienie swego zamiaru. Nie zrażało go niebezpieczeństwo śmierci, przeciwnie - pobudzało pragnienie". Bonawentura z Bangoregio, Legenda maior IX, 7. Fragment ten zamyka cytat z Ps 23,4.
} 
mnie do waszego pana». Gdy Franciszek znalazł się przed obliczem sułtana, dzikie i pełne grozy spojrzenie władcy zmieniło się w samą łagodność, bo dostrzegł w nim męża Bożego. Przez kilka dni pozwolił Franciszkowi głosić wiarę Chrystusową sobie i swoim ludziom i uważnie mu się przysłuchiwał"19.

Kroniki bardzo ogólnie mówią o przebiegu spotkania, w czasie którego ubogi mnich pozyskał sobie życzliwość muzułmańskiego władcy. Św. Franciszek zgodnie ze swoim przekonaniem odważnie świadczył wobec sułtana o Chrystusie i w pokorze, ale również z wielką gorliwością, przepowiadał wobec niego Ewangelię. Nie bał się przejść nawet przez ogień w obecności muzułmańskiego władcy, by udowodnić prawdziwość religii chrześcijańskiej ${ }^{20}$. Jakkolwiek przebiegło spotkanie św. Franciszka z sułtanem Malek al-Kamalem, pewnym jest, że muzułmański władca potraktował Biedaczynę z wielkim szacunkiem i nie tylko pozwolił mu powrócić do obozu krzyżowców, ale ponadto dał braciom pozwolenie na odwiedzenie miejsc świętych w Palestynie ${ }^{21}$. Gorąca wiara Biedaczyny i mądrość pochodząca od Boga tak zafascynowała sułtana, że powiedział: „Gdyby wszyscy byli takimi chrześcijanami jak ty, przyjąłbym waszą wiarę" ${ }^{22}$. Specjalny przywilej sułtana pozwalał, aby naśladowcy św. Franciszka mogli nie tylko bez ograniczeń odwiedzać ojczyznę Chrystusa, ale nawet tam zamieszkać ${ }^{23}$.

Sułtan później podpisał w Jaffie dziesięcioletni układ pokojowy (1229-1239) z cesarzem Fryderykiem II $^{24}$. Dzięki temu chrześcijanie z Zachodu mogli udawać się do Jerozolimy po jej upadku w 1187 r. Wraz z nimi przybyli również bracia mniejsi ${ }^{25}$.

Niewiele wiadomo o pierwszym okresie obecności franciszkanów nad Nilem. Z całą pewnością nie miała ona stałego i ciągłego charakteru. Zakonnicy wykorzystywali nawet krótkotrwałe sukcesy krzyżowców, by móc zaznaczyć swoją obecność. Sposób życia braci franciszkanów, nacechowany żarliwą modlitwą, braterską miłością, ewangelicznym ubóstwem i świadczeniem o prawdzie był podstawowym elementem tej obecności ${ }^{26}$. Posługa franciszkanów polegała najpierw na opiece duchowej nad krzyżowcami, potem zaś nad przedstawicielami królestw europejskich i włoskich republik morskich ${ }^{27}$. Choć zakonnicy

\footnotetext{
19 Jakub z Vitry, Epistula VI, tekst wg Lettres de Jacques de Vitry (1160/70-1240), évêque de Saint-Jean d'Acre. Edition critique, red. R.B. C. Huygens, Leiden 1960.

20 Por. Bonawentura z Bangoregio, Legenda maior IX, 8.

21 Kwestię tę analizuje W. Mruk, Czy św. Franciszek z Asyżu odbyt pielgrzymkę do Jerozolimy?, „Peregrinus Cracoviensis", 22/2011, s. 117-124.

22 Taki wniosek wysnuli biografowie św. Franciszka z powodu nadinterpretacji słów sułtana. Por. G. Basetti-Sani, Saraceni, tłum. M. Miszczyński, w: Leksykon duchowości franciszkańskiej, red. E. Kumka et. al., Kraków-Warszawa 2016, kol. 1767-1768.

23 Zob. I. Gobry, Saint François d'Assise et l'esprit franciscain, Paris 2001, s. 34-35. Nadane franciszkanom prawa, choć w różnym stopniu, były respktowane przez Ajubitów, Mameluków i Osmanów. Por. F. Armanios, Coptic Christianity in Ottoman Egypt, Oxford 2011, s. 82.

24 Później jednak cesarz Fryderyk został ekskomunikowany, o czym mieli go zawiadomić dwaj bracia mniejsi wysłani przez papieża Grzegorza IX.

25 Osiedlili się oni w pobliżu obecnej V Stacji Drogi Krzyżowej i na Górze Syjon w ruinach Wieczernika. Por. M. Brlek, I Francescani a Gerusalemme nel '300, „La Terra Santa”, 46/1970, s. 325-342.

26 Wzór wspólnoty nakreślony wg 2 Reg III, 12. Zob. A. Boni, Wspólnota, tłum. P. Anzulewicz, w: Leksykon duchowości franciszkańskiej, red. E. Kumka et al., kol. 2183-2184.

27 Podobnie było na Bliskim Wschdozie i na wyspach Morza Śródziemnego.
} 
franciszkańscy byli kapelanami Europejczyków ${ }^{28}$ lub pełnili misje dyplomatyczne ${ }^{29}$, nie znaczy to jednak, że ich zapał apostolski ostygł. Zresztą św. Franciszek zostawił w Damietcie swoich braci. Dom zakonny powstał prawdopodobnie przy jego bezpośrednim udziale. Z zachowanych dokumentów z 1220 r. wynika, że bracia mogli się tam zadomowić na dobre. Na terenie enklawy dla kupców bolońskich mieli do dyspozycji dom zakonny i kościół ${ }^{30}$. Jednak już po dwóch latach naśladowcy Biedaczyny musieli opuścić to ważne strategicznie miasto. Wiązało się to z kapitulacją krzyżowców w sierpniu $1221 \mathrm{r}$. Minoryci powracali tam jednak w 1249-1250 i w 1283 r. ${ }^{31}$ Najpierw pobyt franciszkanów był związany z faktem, że święty Ludwik IX, król Francji, zdobył to egipskie miasto ${ }^{32}$. Konwent franciszkański mógł powstać zapewne nieco później, a istniał tylko do kwietnia $1250 \mathrm{r}^{33}$ Warto podkreślić, że Tomasz z Celano pisał swoją relację o życiu Poverella w chwili, gdy król Ludwik IX wyruszał na wyprawę krzyżową ${ }^{34}$. Towarzyszyło mu zresztą kilku braci mniejszych.

Niektórzy zakonnicy w tym czasie ukoronowali swoje życie śmiercią męczeńską. Tak było z bł. bratem Franciszkiem ze Spoleto, który zginął rozcięty piłą, ponieważ nie chciał wyrzec się Chrystusa i przyjąć islamu ${ }^{35}$. W latach 1272-1282 wziętym do niewoli chrześcijanom w Egipcie pomagał brat Giovannino de Ollis z Parmy ${ }^{36}$.

Również na początku XIV w. do Egiptu wysłano pięciu braci, by pracowali wśród niewolników chrześcijańskich. Zaraz po nich przybyli zakonnicy z Francji, którzy osiedlili się w Kairze i w Aleksandrii. W mieście tym otoczyli duchową opieką przebywających tam kupców europejskich. Zakonnicy zostali wysłani przez królową Sancję z Majorki, żonę

\footnotetext{
28 Z listu papieża Aleksandra IV ([1254-1261] Ex relatu) wynika, że opieka duchowa sprawowana przez zakonników na Bliskim Wschodzie polegała na głoszeniu kazań, kierownictwie duchowym oraz słuchaniu spowiedzi. Zob. M. Adinolfi, G.B. Bruzzone, In Terra Santa con i papi, Casale Monferrato 2000, s. 29-30.

29 Jak zauważono, ,począwszy od XIII wieku, kiedy chodziło o wysyłanie posłów na Wschód - Bliski, Środkowy czy Daleki - Kuria [Rzymska] szczególnym zaufaniem obdarzała franciszkanów”; H.E. Mayer, The Crusades, Oxford $1988^{2}$, s. 225.

30 Źródła wspomianają: Ecclesia in qua habitant Fratres Minores; Cronaca della Missione, Chiesa, Convento e Parrocchia di S. Caterina in Alessandria d'Egitto (dagli inizi all'anno 1956), red. M. Bellenzier, L. Cruciani, „Studia Orientalia Christiana Collectanea”, 26-27/1996, s. 492.

31 Na temat obecności franciszkańskiej w Damietcie zob. M. Roncaglia, St. Francis of Assisi and the Middle East, Cairo $1957^{3}$, s. 48-49.

32 Pod wodzą króla Francji św. Ludwika IX (1214-1270) krzyżowcy 6 czerwca 1249 r. zajęli Damiettę. Nie wykorzystali jednak tego zwycięstwa, bo już w lutym 1250 r. ponieśli klęskę w bitwie pod Mansurah. Święty król Francji zmarł podczas oblężenia miasta Tunis w czasie VIII krucjaty. Zob. M. Jacov, Proposta per un'analisi comparata tra il fenomeno delle sette crociate e delle quattro leghe sante, sullo sfondo dell'evoluzione storica dal medioevo all'età moderna, tra Europa e Vicino Oriente, „Perspektywy Kultury”, 11/2014, nr 2, s. 221-222; W. Lorek, Krucjaty Ludwika IX Świętego 1248-1270, Oświęcim 2015, s. 48-50.

33 Zob. W. Mruk, Działalność franciszkanów w Ziemi Świętej w XIII wieku, w: Krucjata bez krucjat. O franciszkanach na ziemiach islamu, red. A. Zając, Kraków 2011, s. 93.

34 Por. M.F. Cusato, Healing the Violence of the Contemporary World. A Franciscan Paradigm for Dialogue with Islam, w: St. Francis and the Sultan, 1219-2019. A Commemorative Booklet, red. M. Calabria, Cincinati-Rome 2019, s. 22.

35 A. Elli, Storia della Chiesa copta, t. 3: Appendici, bibliografia, indici, Cairo-Jerusalem 2003, „Studia Orientalia Christiana Monagraphiae", t. 13, s. 37, przyp. 9. Autor powołuje się na Kronikę M. Bellenziera.

36 Por. W. Mruk, Działalność franciszkanów, s. 100.
} 
króla Roberta Andegaweńczyka ${ }^{37}$. To dzięki zabiegom tej pary królewskiej duchowi synowie św. Franciszka mogli na stałe osiedlić się w miejscach świętych ${ }^{38}$.

Obecność minorytów także i wtedy była okupiona krwią męczeńską. Prześladowania nasilały się, gdy islamscy władcy Egiptu czuli się pewnie na swym tronie. Tak było w epoce mameluków ${ }^{39}$, a później na początku dominacji osmańskiej ${ }^{40}$. Druga połowa XIV w. przyniosła szczególnie ciężkie prześladowania chrześcijan. W tym czasie wielu zakonników oddało życie za wiarę w Chrystusa w różnych miejscach rozległego państwa Mameluków (Kair ${ }^{41}$, Damaszek, Gaza, Jerozolima). Władcy muzułmańscy, wcześniej pokojowo nastawieni wobec chrześcijan i życzliwi dla franciszkanów, zmienili swoje nastawienie radykalnie ${ }^{42}$.

W 1345 r. brat Liwiusz z Francji, ogarnięty duchem apostolskim, głosił Ewangelię Saracenom w Kairze. Został za to bestialsko zamordowany ${ }^{43}$. Inni bracia szli jego śladem i bez najmniejszego wahania głosili publicznie Chrystusa i polemizowali z błędami muzułmanów. Dziś taka postawa może być oceniana jako niezrozumiała i nietolerancyjna. Zdarzały się także odstępstwa, ale te często kończyły się powrotem na łono chrześcijaństwa i śmiercią męczeńską ${ }^{44}$.

W latach 1382-1516 panował łagodniejszy niż wcześniej reżim islamski. Władza centralna znajdowała się w Kairze, a całe państwo podzielono na prowincje (mamlaka) i okręgi (niyaba). W przeciwieństwie do Ajubitów, którzy obawiali się powrotu krzyżowców i pozostawiali w ruinie warowne zamki i porty nadmorskie, mamelucy starali się o rozwój wymiany handlowej i życie społeczne. Niektóre porty były centrami wymiany towarów z krajami europejskimi. Jednak od początku XV w. władcy mameluccy pozostawali właściwie samym sobie dalekie prowincje, skupiając się wyłącznie na zarządzaniu Kairem i okolicami ${ }^{45}$. Dla mameluków transport pielgrzymów był działalnością bardzo dochodową. Wszelkie niepokoje były więc niepożądane, choć stosowano odwet za akty piractwa na Morzu Śródziemnym

\footnotetext{
37 Sancja to córka Jakuba I Zdobywcy - króla Majorki. Robert, zwany „Mądrym”, odziedziczył tron królewski Neapolu po swoim ojcu Karolu II. Para królewska tak była przywiązana do franciszkanów, iż przed śmiercią oboje zdecydowali się obrać życie zakonne. Sancja zmarła jako klaryska w 1345 r.

38 Król Robert zakupił od sułtana Egiptu Wieczernik oraz prawo sprawowania liturgii przy Bożym Grobie, zaznaczając przy tym, iż jedynie bracia mniejsi mogą cieszyć się tymi przywilejami i reprezentować całe chrześcijaństwo zachodnie. J.H. [J. Herrojo], La Spagna, il regno di Napoli e la Terrasanta, w: M. Piccirillo, op. cit., s. 184.

39 Mamelucy okazali się ostatecznymi zwycięzcami nad krzyżowcami, tworząc w Egipcie państwo, które przetrwało przez prawie 260 lat. Islamscy władcy z tej dynastii opierali swą potęgę na egipskich żołnierzach, wywodzących się spośród chłopców wykupowanych na targach niewolników. Byli potem wyzwalani i stawali się arystokracją, gwardią przyboczną sułtana i trzonem jego armii. Zob. A. Clot, L'Égypte des mamelouks. L'empire des esclaves (1250-1517), Paris 1996.

40 Imperium Osmanów rozciągnęło swe panowanie na tereny bliskowschodnie na skutek zwycięstwa Salima w 1516 r. w bitwie pod Marg Dabiq z Mamelukami. Por. P.K. Hitti, Dzieje Arabów, tłum. W. Dembski, M. Skuratowicz, E. Szymański, Warszawa 1969, s. 590-592.

41 Franciszkanie byli obecni w Kairze niedaleko kościoła św. Sergiusza (Abu Sarga) już od XIV w.

4214 listopada 1391 r. palmę męczeństwa otrzymali pierwsi bracia mniejsi z Kustodii Ziemi Świętej. Byli to św. Mikołaj Tavelic oraz jego trzej współbracia: Szczepan z Cuneo, Piotr z Narbony i Deodat z Rodez. Na temat męczeństwa tych zakonników por. J. Briand, Sion, Jerusalem 1973, s. 77-82.

43 Pięcioosobowa grupa braci mniejszych dołączyła tam w 1307 r. Zob. A. Elli, Storia della Chiesa copta, t. 3, s. 37, przyp. 9.

44 Chodzi np. o Jana, zakonnika pochodzenia hiszpańskiego. Zob. ibidem, s. 37, przyp. 9.

45 Za decentralizacją administracji i biernością sułtanów szła samowola zarządców, którzy nakładali na ludność cywilną ogromne podatki. Chłopi opuszczali więc ziemię i wracali do nomadyzmu, ponieważ mogli uniknąć ucisku fiskalnego. Por. B. Saletti, I francescani in Terrasanta (1291-1517), Padova 2016, s. 163-164.
} 
ze strony chrześcijan ${ }^{46}$. W końcu jednak pod groźbą strasznych konsekwencji porzucano takie zamiary.

Z nastaniem epoki osmańskiej (1517 r.) Egipt zapadł w stan letargu, stał się zapomnianą prowincją wielkiego imperium. Jedynie handel i ruch pielgrzymkowy do Palestyny stanowił atut kraju nad Nilem. W Egipcie Turcy ustanowili namiestników sułtana z tytułem paszy ${ }^{47}$ oraz uszanowali przywileje niektórych grup etnicznych i religijnych ${ }^{48}$. Sułtan dążył jednak do tego, by jego władza objęła całość społeczności zamieszkującej imperium, a miał temu służyć system tzw. milletu ${ }^{49}$. To właśnie wtedy obecność franciszkanów zinstytucjonalizowała się i mogła się rozwijać. Bracia mniejsi nie musieli ograniczać swoich kontaktów do przyjezdnych kupców czy dyplomatów lub najwyżej towarzyszyć pielgrzymom, których okręty weneckie przywoziły z Europy do Egiptu, a potem transportowały dalej na palestyński brzeg ${ }^{50}$.

\section{Obecność instytucjonalna}

Dopiero na początku XVII w. franciszkanie na dobre osiedli nad Nilem. Wcześniej ta obecność miała charakter prowizoryczny i niepewny. Duszpasterstwo mogło być prowadzone przy drzwiach zamkniętych. Udzielano sakramentów tylko w prywatnych i klasztornych kaplicach, w domach prywatnych, a nierzadko również w zwykłych zajazdach, gdzie przyjmowano kupców z Europy (tzw. funduq) $)^{51}$. Przez dwie dekady ochrzczono wtedy trzydzieści osób. W księgach metrykalnych odnotowano osiem ślubów katolickich ${ }^{52}$.

W 1630 r. o. Paweł z Lodi został nominowany pierwszym prefektem misji w Egipcie (Praefectus Missionis Aegypti) $^{53}$. Przybył on do Kairu z Jerozolimy. Otrzymał od papieża Urbana VIII list adresowany do ówczesnego patriarchy Kościoła koptyjskiego Jana XV (1619-1634), który był skłonny do unii z Rzymem ${ }^{54}$. Jednak adresat zmarł i list nie został mu on doręczony. O. Paweł zamieszkał w rezydencji ambasadora Wenecji w Kairze. Niedaleko powstał natomiast klasztor dla braci ${ }^{55}$. W celu ustanowienia stałego klasztoru kupiec wenecki Dominik Savio ofiarował zakonnikom franciszkańskim własny dom przylegający do prezbiterium i chóru kaplicy Wenecjan. W 1633 r. Wenecjanin Jan Donato otrzymał pozwolenie na

\footnotetext{
46 Por. ibidem, s. 167.

47 A. Elli, Storia della Chiesa copta, t. 2, s. 258-261.

48 Po 1516 r. prawosławny patriarcha Konstantynopola stał się najwyższym sędzią w zakresie spraw cywilnych. On i duchowieństwo prawosławne byli zwolnieni z podatku pogłównego. Por. H. Tuchle, A. Bouman, Historia Kościoła, t. 3: 1500-1715, thum. J. Piesiewicz, Warszawa 1986, s. 260-261.

49 Oznaczał on, że każda wspólnota religijna i narodowa posiadała autonomię, kierując się prawami partykularnymi oraz własnymi zwyczajami. Zgodnie z nauką Koranu, przedstawiciele „ludu Księgi” nie musieli przechodzić na islam; por. J. i D. Sourdel, Cywilizacja islamu, thum. M. Skuratowicz, W. Dembski, Warszawa 1980, s. 48.

50 Portem docelowym była Jaffa.

51 Funduq, w: C. Glassé, The New Encyclopedia of Islam, New York 2001, s. 151.

52 Dane wg L. Van Zeelst, Franciscans in Egypt, w: The Coptic Encyclopedia, t. 4, red. A.S. Atiya, New York 1991, s. 1121-1122.

53 Por. G. Manfredi, La figura del „Praefectus Missionum” nelle Prefetture d'Egitto-Etiopia e dell'Alto Egitto Etiopia affidate ai Frati Minori (1630-1792), ,Studia Orientalia Christiana Analecta”, 10/1958, s. 50-52.

54 Por. S.Y. Labaib, John XV, w: The Coptic Encyclopedia, t. 4, s. 1347.

55 Por. A. Elli, Storia della Chiesa copta, t. 2, s. 272-273; t. 3, s. 38-39.
} 
sprowadzenie franciszkanów do Aleksandrii i ich osiedlenie się w tym mieście ${ }^{56}$. W porcie w Aleksandrii często zatrzymywali się zakonnicy udający się do Jerozolimy. W tym samym czasie założono nowy dom zakonny także w Rossetcie. Osiedlali się tam głównie bracia z prowincji florenckiej. W Kairze do grupy innych zakonników dołączyli franciszkanie francuscy ${ }^{57}$. Kair (dzielnica Musky) i Aleksandria, gdzie w 1632 r. stanęły kościoły, stanowiły dwa najważniejsze centra duszpasterskie na północy Egiptu. Przez dwa kolejne wieki następował powolny rozwój: powstawały parafialne szkoły ${ }^{58}$, kaplice, dzieła charytatywne ${ }^{59}$.

Nie zawsze jednak stosunki z kupcami europejskimi i dyplomatami układały się dobrze. Działalność misyjna mogła utrudniać Europejczykom kontakty ekonomiczne z muzułmanami. To z tego powodu franciszkanie musieli opuścić w 1643 r. swoją siedzibę w Kairze na terenie rezydencji konsulów francuskiego i weneckiego ${ }^{60}$.

Już w niezależnym od dyplomatów kairskim klasztorze ustanowiono rezydencję prefekta kościelnego, a pod koniec XVII w. także studium języków orientalnych, w tym arabskiego. W październiku 1633 r. Kongregacja Krzewienia Wiary (Propaganda Fide) ${ }^{61}$ powołała do istnienia franciszkańską prefekturę Etiopii ${ }^{62}$. Powierzono ją o. Antonio da Virguletta. Przydzielono mu także trzech zakonników do pomocy ${ }^{63}$. Franciszkanie, którzy mieli zamiar dotrzeć do Etiopii, otrzymali od patriarchy koptyjskiego pozwolenie, by rezydować w dwóch klasztorach na pustyni egipskiej: św. Antoniego i św. Makarego ${ }^{64}$. Mieli tam doskonalić język arabski i w odpowiednim czasie przyłączyć się do karawan zdążających w kierunku „rogu Afryki”. Stolica Apostolska regularnie wspomagała finansowo te monastyry ${ }^{65}$.

Pomiędzy 1633 a 1669 franciszkanie udawali się trzykrotnie na teren Etiopii. Jednak wielu braci zmarło z powodu chorób, a inni ponieśli śmierć męczeńską ${ }^{66}$. Z powodu tych trudności nie mogła więc powstać w tym kraju żadna stała wspólnota zakonna lub pracówka misyjna. W 1671 r. prefektura Egiptu została połączona z etiopską. W 1680 r. kustosz Ziemi Świętej o. Piermarino Sormanni otrzymał także tytuł prefekta Egiptu. Swoją posługę sprawował

56 Zob. Custodia Terrae Sancte, The foundation of the Mouski convent, https://www.custodia.org/en/history-mouski (dostęp 23.02. 2021).

57 Zob. Cronaca della Missione, Chiesa, Convento e Parrocchia, s. 51.

58 Pierwsza katolicka szkoła powstała w Kairze ok. 1730 r. Zob. O.F. A. Meinardus, Christians in Egypt: Orthodox, Catholic, and Protestant Communities Past and Present, Cairo 2010, s. 117.

59 Por. B. Rossi, La Custodia di Terra Santa, Jerusalem 1979, s. 93-94.

60 Por. G. Giamberardini, Accenni storici sulla missione francescana dell 'Alto Egitto, „La Voce del Nilo”, 18/1959, s. 157 .

61 Powołana przez papieża Grzegorza XV na mocy konstytucji Inscrutabili Divinae Providentiae (22 czerwca 1622 r.). Organizacyjnie kongregacja okrzepła około 1650 r. Ten urząd Kościoła koordynował działalność misyjną, nadając jej niespotykany do tej pory rozmach. Por. J.A. Griffin, The Sacred Congregation de Propaganda Fide. Its Foundation and Historical Antecedents, w: Christianity and Missions, 1450-1800, red. J.S. Cummins, Aldershot 1997, s. 57-95.

62 Wiele dokumentów zostało opublikowanych w: T. Somigli, G.M. Montano, Etiopia francescana nei documenti dei secoli XVII e XVIII, t. 1-2, Firenze 1928-1948.

63 Por. A. Elli, Storia della Chiesa Ortodossa Tawāhedo d'Etiopia, t. 1-2, Milano 2017, „Studia Orientalia Christiana Monographiae", t. 25, s. 947-949.

64 Por. O.F. A. Meinardus, The Capuchin Missionary Efforts in the Coptic Monasteries, „Studia Orientalia Christiana Collectanea", 20/1987, s. 195-196.

65 Zob. A. Elli, Storia della Chiesa copta, t. 3, s. 38-39, przyp. 14.

66 Pod koniec sierpnia 1641 r. zmarł z wycieńczenia sam prefekt Antoni da Virguletta. Por. G. Manfredi, op. cit., s. 57-59. 
za pośrednictwem wiceprefekta rezydującego w Kairze. Na początku 1687 r. rzymska kongregacja Propaganda Fide zadecydowała o podziale istniejącej prefektury na część obejmującą Dolny Egipt, która pozostawała w gestii Kustosza Ziemi Świętej, oraz niezależną, nową prefekturę apostolską. Tę ostatnią powierzono Braciom Mniejszym Ściślejszej Obserwancji (reformatom) z Toskanii ${ }^{67}$. W 1717 r. jurysdykcja tej prefektury obejmowała już tylko Górny Egipt ${ }^{68}$.

Praca misyjna w Etiopii okazała się niemożliwa, więc bracia mniejsi skierowali swoje wysiłki ku wspólnocie Koptów. W ten sposób rozpoczęła się długa i trudna działalność duszpasterska. Praktycznie od XVIII w. franciszkanie prowadzili zorganizowane duszpasterstwo dla tych wiernych. Na terytorium Bliskiego Wschodu pracowali bracia z Zakonu Braci Mniejszych Obserwantów (w Polsce zwanych ,,bernardynami”), a także w przypadku ściślejszej obserwacji określani jako ,reformaci” ${ }^{69}$.

Zakonnicy pracujący w Egipcie na terytorium podległym Kustodii Ziemi Świętej mogli podjąć apostolat nie tylko za zgodą Kongregacji Krzewienia Wiary, ale także za zezwoleniem generała zakonu. Otrzymywali tytuł ,misjonarza apostolskiego” i mieli obowiązek pozostawać na terenach bliskowschodnich misji franciszkańskich przez 12 lat. Inni przebywali tylko za zgodą generała zakonu i nazywano ich „wizytującymi”, a ich posługa trwała sześć lat. Misjonarze apostolscy byli zazwyczaj głównymi duszpasterzami lokalnych wspólnot parafialnych, rekrutujących się w większości z ludności arabskiej, drudzy zaś ich pomocnikami ${ }^{70}$.

W 1719 r. kongregacja Propaganda Fide uznała za właściwe, aby podzielić zadania między dwie gałęzie franciszkańskie, aby w ten sposób praca misyjna stała się skuteczniejsza ${ }^{71}$. Utworzono nową misję dla Koptów (ad Cophtos lub pro Cophtis). Tytuł biskupa „Akhmim-Mokha-Sokotra" był związany z prefektem apostolskim niezależnym od Kustodii Ziemi Świętej. Dom zakonny w Kairze został podzielony na dwie części: jedna dla pełniących służbę w Ziemi Świętej, a druga dla franciszkanów - reformatów. Każda część miała odrębnego przełożonego zakonnego i zachowywała swobodę w działaniu. Do Kustodii Ziemi Świętej należała wyłącznie jurysdykcja parafialna nad katolikami wschodnimi, gdy ci nie mieli własnego duszpasterza ${ }^{72}$. Chociaż misja pro Cophtis miała jako cel Etiopię, jednak ze względu na ścisłe więzi Kościoła etiopskiego z Kościołem w Egipcie konstytucja apostolska Eo quamvis tempore papieża Benedykta XIV (1740-1758) z 1745 r. określiła rolę misjonarza jako wspomagającego dzieło pojednania hierarchii i kleru wschodniego z Kościołem rzymskim. Bez względu na trudności i nieporozumienia, misjonarze franciszkańscy dzielili z duchowieństwem koptyjskim kościoły i obowiązki duszpasterskie przez okres 157 lat ${ }^{73}$.

\footnotetext{
${ }_{67}$ Por. A. Elli, Storia della Chiesa copta, t. 3, s. 40.

68 Dokumentacja dotycząca tej prefektury została opublikowana w trzech tomach przez G. Giamberardiniego w serii „Studia Orientalia Christiana Aegyptiaca”, t. 14-16, Cairo 1960-1962.

69 Od 1897 r. stanowią jedną rodzinę zakonną Zakonu Braci Mniejszych. Na ten temat por. M. Daniluk et al., Franciszkanie, w: Encyklopedia Katolicka, t. 5, red. L. Bieńkowski et al., Lublin 1989, kol. 473-501.

70 Zob. A. Szteinke, Polscy Bracia Mniejsi w stużbie Ziemi Świętej 1342-1995, Poznań 1999, s. 18.

71 Pragnący pracować na Bliskim Wschodzie uczyli się miejscowych języków, głównie arabskiego. Placówkami kształcącymi w tym kierunku były kolegia: św. Bartłomieja na wyspie tyberyjskiej i św. Piotra na Monte Aureo.

72 Por. A. Colombo, La nascita della Chiesa Copto-Cattolica nella prima metà del 1700, Roma 1996, „Orientalia Christiana Analecta", t. 25, s. 5-6; 41.

73 Por. A. Elli, Storia della Chiesa copta, t. 3, s. 41, przyp. 24.
} 
Egipt w epoce osmańskiej jawił się jako jeden z najtrudniejszych terenów misyjnych Kościoła. Suchy, gorący klimat był niezwykle uciążliwy dla Europejczyków, nawet z krajów śródziemnomorskich: dzienne upały i nocne chłody utrudniały życie. W Aleksandrii wilgotne powietrze wzmagało dyskomfort. Na terenie Egiptu ścierały się wpływy chrześcijańskie: miejscowej wspólnoty koptyjskiej, melchitów i łacinników. Duchowni wchodzili sobie wzajemnie w kompetencje. Odmienność kultur i tradycji stawiała w opozycji Europejczyków i autochtonów; utrudniała współżycie i powodowała konflikty i nieustanne wzajemne oskarżenia $^{74}$.

W takich warunkach mogli pracować jedynie misjonarze o żelaznym zdrowiu i wyjątkowych cechach charakteru. Szczególnie zwierzchnicy musieli być ludźmi wielkiego taktu i delikatności, by nie dać się wciągnąć w polityczne rozgrywki, być ponad podziałami, z dala od intryg i denuncjacji. Mimo obiektywnych trudności, był to jednak czas pełen plonów duchowych. Bracia, głównie proweniencji włoskiej, nigdy nie starali się założyć Kościoła lokalnego obrządku rzymskiego, ale raczej pamiętali, że wysłano ich, by wspomagać Koptów ${ }^{75}$. Starali się więc o założenie i rozwój katolickiego Kościoła koptyjskiego.

W tym samym czasie śladem braci mniejszych poszli jezuici, którzy starali się zintegrować z miejscową wspólnotą koptyjską. Franciszkanie opiekowali się Koptami, którzy przyjęli katolicyzm. Powrót do jedności z Kościołem nie polegał na przyjęciu obrządku rzymskiego. Tak było w przypadku Justusa Maraghi i Rafaela al-Tukhi, których bracia mniejsi wysłali do Rzymu na studia. Obaj zostali tam wyświęceni na kapłanów. Maraghi został potem biskupem $^{76}$. Z kolei Rafael al-Tukhi ze względu na słabe zdrowie wrócił w 1735 r. do Rzymu, by pracować nad wydaniami koptyjskich ksiąg liturgicznych. Ten katolicki kapłan obrządku koptyjskiego bazował na manuskryptach, które znajdowały się w Watykanie ${ }^{77}$. W XVIII w. szerzej zaczęto interesować się zabytkami starożytnymi w Egipcie. Pionierami egiptologii bywali nierzadko katoliccy duchowni ${ }^{78}$.

W 1746 r. Koptowie pozostający w jedności z Rzymem otrzymali swego pierwszego zwierzchnika. Dzięki obecności braci mniejszych egipska wspólnota katolicka powoli się rozrastała $^{79}$. Wtedy jurysdykcja prefekta Egiptu została ograniczona do samych zakonników i niekoptyjskich wiernych ${ }^{80}$. W epoce, gdy władzę pojmowano w specyficzny sposób i do rzadkości należało przyznawanie praw mniejszościom, można dostrzec, jak wielkim wyczuciem oraz poszanowaniem wrażliwości europejskiej, koptyjskiej i arabskiej odznaczali się pasterze Kościoła katolickiego reprezentowanego nad Nilem przez franciszkanów.

\footnotetext{
74 Podobnie było na całym terytorium misyjnym Bliskiego Wschodu. Zob. G. Buffon, Les Franciscains en Terre Sainte. De l'espace au territoire, entre opposition et adaptation, w: New Faith in Ancient Lands. Western Missions in the Middle East in the Nineteenth and Early Twentieth Centuries, red. H. Murre-van den Berg, Leiden 2006, „Studies in Christian Mission”, t. 32, s. 65-91.

75 Zob. G. Basetti-Sani, Il carattere particolare della Missione Francescana dell'Alto-Egitto ,, in auxilium Cophtorum”, „Studi Francescani”, 47/1951, s. 55-73.

76 Zob. P.B. T. Bilaniuk, Coptic relations with Rome, w: The Coptic Encyclopedia, t. 2, s. 610.

77 Por. R. al-Tukhi, Rufa 'il al-Tukhi (1701-1787), w: The Coptic Encyclopedia, t. 7, s. 2067-2068; A. Elli, Storia della Chiesa copta, t. 3, s. 41, 44.

78 Przede wszystkim Claude Sicard (1676-1726) i Richard Pococke (1704-1765); zob. A. Elli, Storia della Chiesa copta, t. 3, s. 42-43.

79 Patriarchat katolicki w Aleksandrii wznowił swą działalność w 1895 r.

80 Por. L. Van Zeelst, op. cit., s. 1122.
} 
W głębi Egiptu pracowali zakonnicy wydelegowani do misji wśród wiernych koptyjskich, będący jednak w służbie Ziemi Świętej. Rezydowali oni w Akhmim, Fajum i Fidimin, utrzymując stałą obecność w Aleksandrii i na terenie Rosetty. Zaledwie jednak minęła połowa XVIII stulecia, gdy wybuchło prześladowanie katolików w Kairze. W jego wyniku zburzono jeden z kościołów, a inne zamknięto. Hierarchowie i zakonnicy znaleźli się w więzieniu. Na szczęście „nawałnicę [represji] uspokojono dzięki dużym nakładom pieniędzy”, co pozwoliło na odzyskanie świątyń i uwolnienie więźniów - zanotował jeden z ówczesnych kronikarzy ${ }^{81}$.

W Egipcie pod jarzmem osmańskim groźby bywały często bardzo realne i prowadziły do apostazji. Tak było jeszcze na początku XVIII w. Szczególne wydarzenia wiążą się z o. Franciszkiem Klemensem ${ }^{82}$, kapelanem konsula francuskiego w Kairze ${ }^{83}$. Zakonnik ten najpierw przyjął islam, idąc śladem niegodnego dyplomaty ${ }^{84}$, lecz potem uznał swój błąd i mężnie wyznał wiarę. Przypłacił ten akt odwagi życiem. Pod groźbą śmierci zakazano Koptom uczęszczania do „kościołów Franków” (katolickich) ${ }^{85}$. Z tego okresu próby zrodziło się jednak wielkie dobro. Jeden z ortodoksyjnych biskupów koptyjskich powrócił do jedności ze Stolicą Piotrową. Był to Antoni Fulayfil, którego nominowano pierwszym wikariuszem apostolskim dla Koptów (1761). Pozbawieni możliwości budowy własnych kościołów katoliccy kapłani koptyjscy sprawowali liturgię w świątyniach franciszkańskich ${ }^{86}$. Bracia mniejsi spieszyli im z pomocą i posługą dla wiernych.

Od drugiej połowy XVIII w. prefektura egipska zasilana była przez misjonarzy przybywających nie tylko z terytorium Francji czy Włoch, ale także między innymi z Polski. U schyłku XVIII stulecia pracowali w Egipcie o. Herkulan Glinger, o. Maurycy Pigner i o. Anastazy Peterski ${ }^{87}$.

Na przełomie XVII i XVIII w. stale wzrastała w Egipcie liczba rzymskich katolików. Dopiero jednak papież Grzegorz XVI na mocy motu proprio z 18 maja 1839 r. erygował Wikariat Apostolski Egiptu i Arabii. Tym samym zamknął się rozdział prefektury kościelnej w Dolnym Egipcie, związanej z Kustodią Ziemi Świętej. Aż do czasów współczesnych wikariuszem apostolskim Aleksandrii dla rzymskich katolików był zawsze franciszkanin, a w czterech przypadkach był to wcześniejszy kustosz Ziemi Świętej ${ }^{88}$.

\section{Zakończenie}

Wielowiekowa obecność franciszkanów nad Nilem ewoluowała i przechodziła różne etapy. Każdy kolejny okres historyczny przynosił zmiany. Epopei franciszkańskiej w Egipcie

\footnotetext{
81 A. Elli, Storia della Chiesa copta, t. 3, s. 45-46, przyp. 44.

82 Należał do gałęzi zakonu zwanej „rekolektami”. Wspomina o nim A. Du Monstier, Martyrologium Franciscanum in quo sancti, beati, aliiqui servi Dei, martyres, pontifices, confessores, ac virgines..., Roma 1938 i G.-C. Guzzo, Il Libro d'Oro dei Francescani di Terra Santa, Venezia 1939, s. 482-489. Zob. A. Elli, Storia della Chiesa copta, t. 3, s. 37-38, przyp. 9.

83 Był to Benoît de Maillet. O tej kontrowersyjnej postaci por. ibidem, t. 2, s. 277, przyp. 66.

84 Konsulat francuski w tym okresie nazywano nawet, „synagogą szatana”. Zob. P.B. T. Bilaniuk, op. cit., s. 610.

85 Począwszy od wypraw krzyżowych, tak nazywano na Bliskim Wschodzie przybyszów z Europy.

86 Por. A. Elli, Storia della Chiesa copta, t. 3, s. 45-46.

87 T. Moskal, ,...Zastaliśmy w zakrystii Turka w zawoju, z broda ogromną”. Adam Prosper Burzyński OFM (1755-1830) jako prefekt apostolski w Egipcie, w: Kościót w Polsce, Dzieje i kultura, red. J. Walkusz, t. 15, Lublin 2016, s. 74-75.

${ }^{88}$ Ibidem, s. 51-52, przyp. 60.
} 
nadawały kształt wydarzenia historyczne na Bliskim Wschodzie i w Afryce Północnej. Stale jednak widać było dynamizm misyjny i apostolski braci mniejszych. Nie zrażali się oni trudnościami i potrafili podejmować nowe wyzwania. Od XVII w. pojawiły się nowe pola działania. Okres stanowiący przełom XIX i XX stulecia oznaczał rozkwit wspólnoty katolickiej w Egipcie. Franciszkanie, jak również często powierzeni im wierni, wywodzili się z różnych narodów. Właśnie ten międzynarodowy aspekt duszpasterstwa i wszelkiej innej działalności oraz samej wspólnoty zakonnej wydaje się bardzo charakterystyczny. Potwierdzają to już kolejne dziesięciolecia XIX i XX w. oraz początek obecnego stulecia.

\section{Bibliografia}

Adinolfi M., Bruzzone G. B., In Terra Santa con i papi, Casale Monferrato 2000.

al-Tukhi R., Rufa'il al-Tukhi (1701-1787), w: The Coptic Encyclopedia, t. 7, red. A.S. Atiya, New York-Toronto 1991, s. 2067-2068.

Armanios F., Coptic Christianity in Ottoman Egypt, Oxford 2011.

Basetti-Sani G., Il carattere particolare della Missione Francescana dell'Alto-Egitto „, in auxilium Cophtorum”, „Studi Francescani”, 47/1951, s. 55-73.

Basetti-Sani G., Saraceni, tłum. M. Miszczyński, w: Leksykon duchowości franciszkańskiej, red. E. Kumka et. al., Kraków-Warszawa 2016, kol. 1753-1772.

Bilaniuk P.B. T., Coptic relations with Rome, w: The Coptic Encyclopedia, t. 2, red. A.S. Atiya, New York-Toronto 1991, s. 609-611.

Boni A., Wspólnota, tłum. P. Anzulewicz, w: Leksykon duchowości franciszkańskiej, red. E. Kumka et. al., Kraków-Warszawa 2016, kol. 2165-2186.

Briand J., Sion, Jerusalem 1973.

Brlek M., I Francescani a Gerusalemme nel '300, „La Terra Santa”, 46/1970, s. 325-342.

Buffon G., Les Franciscains en Terre Sainte. De l'espace au territoire, entre opposition et adaptation, $\mathrm{w}$ : New Faith in Ancient Lands. Western Missions in the Middle East in the Nineteenth and Early Twentieth Centuries, red. H. Murre-van den Berg, Leiden 2006, „Studies in Christian Mission”, t. 32, s. 65-91.

Clot A., L'Égypte des mamelouks. L'empire des esclaves (1250-1517), Paris 1996.

Colombo A., La nascita della Chiesa Copto-Cattolica nella prima metà del 1700, Roma 1996, „Orientalia Christiana Analecta", t. 250.

Cronaca della Missione, Chiesa, Convento e Parrocchia di S. Caterina in Alessandria d'Egitto (dagli inizi all'anno 1956), red. M. Bellenzier, L. Cruciani, „Studia Orientalia Christiana Collectanea”, 26-27/1996, s. 5-640.

Cusato M. F., Healing the Violence of the Contemporary World. A Franciscan Paradigm for Dialogue with Islam, w: St. Francis and the Sultan, 1219-2019. A Commemorative Booklet, red. M. Calabria, Cincinati-Rome 2019, s. 1-37.

Custodia Terrae Sancte, The foundation of the Mouski convent, https://www.custodia.org/en/history-mouski (dostęp 23.02.2021).

Daniluk M. et al., Franciszkanie, w: Encyklopedia Katolicka, t. 5, red. L. Bieńkowski et al., Lublin 1989, kol. 473-501.

de Ghyvelde F. [Janssoone], L'Egypte et les Franciscains. Épisodes de la dernière guerre (documents inédits), [Québec] 1897.

Du Monstier A., Martyrologium Franciscanum in quo sancti, beati, aliiqui servi Dei, martyres, pontifices, confessores, ac virgines..., Roma 1938. 
Elli A., Storia della Chiesa copta, t. 1: Nascita e splendore del cristianesimo egiziano, t. 2: L'Egitto arabo e musulmano, t. 3: Appendici, bibliografia, indici, Cairo-Jerusalem 2003, „Studia Orientalia Christiana Monographiae", t. 12-14.

Elli A., Storia della Chiesa Ortodossa Tawāhedo d'Etiopia, t. 1-2, Milano 2017, „Studia Orientalia Christiana Monographiae", t. 25.

Gerhards A., Brakmann H., Die Koptische Kirche, Stuttgart 1994.

Giamberardini G., ,,Historia” della missione francescana in Alto Egitto-Fungi-Etiopia, 1686-1720, scritta dal P. Giacomo d'Albano, Cairo 1961, „Studia Orientalia Christiana Aegyptiaca”, t. 15.

Giamberardini G., Accenni storici sulla missione francescana dell'Alto Egitto, „La Voce del Nilo”, 18/1959, s. 157-160; 205-211.

Giamberardini G., Cronaca della missione francescana dell'Alto Egitto: 1719-1739, scritta dal P. Ildefonso da Palermo, Cairo 1962, „Studia Orientalia Christiana Aegyptiaca”, t. 16.

Giamberardini G., Lettere dei prefetti apostolici dell'Alto Egitto nel secolo XVIII, Cairo 1960, „Studia Orientalia Christiana Aegyptiaca”, t. 14.

Glassé C., The New Encyclopedia of Islam, New York 2001.

Gobry I., Saint François d'Assise et l'esprit franciscain, Paris 2001.

Griffin J. A., The Sacred Congregation de Propaganda Fide. Its Foundation and Historical Antecedents, w: Christianity and Missions, 1450-1800, red. J.S. Cummins, Aldershot 1997, s. 57-95.

Guzzo G.-C., Il Libro d'Oro dei Francescani di Terra Santa, Venezia 1939.

Habib al-Masri I., L'Église invincible, „Le Monde Copte”, 9/1980, s. 28-31.

Herrojo J., La Spagna, il regno di Napoli e la Terrasanta, w: In Terrasanta. Dalla Crociata alla Custodia dei Luoghi Santi, red. M. Piccirillo, Firenze-Milano 2000, s. 183-185.

Hitti P. K., Dzieje Arabów, tłum. W. Dembski, M. Skuratowicz, E. Szymański, Warszawa 1969.

Hoose A. L., Francis of Assisi's way of peace? His conversion and mission to Egypt, „The Catholic Historical Review", 96/2010, nr 3, s. 449-469.

House A., Święty Franciszek z Asyżu, tłum. B. Nawrot, Warszawa 2002.

Jacov M., Proposta per un'analisi comparata tra il fenomeno delle sette crociate e delle quattro leghe sante, sullo sfondo dell'evoluzione storica dal medioevo all'età moderna, tra Europa e Vicino Oriente, „Perspektywy Kultury”, 11/2014, nr 2, s. 195-233.

Labaib S. Y., John XV, w: The Coptic Encyclopedia, t. 4, red. A.S. Atiya, New York-Toronto 1991, s. 1347.

Lettres de Jacques de Vitry (1160/70-1240), évêque de Saint-Jean d'Acre. Edition critique, red. R.B.C. Huygens, Leiden 1960.

Lorek W., Krucjaty Ludwika IX Świętego 1248-1270, Oświęcim 2015.

Manfredi G., La figura del „Praefectus Missionum” nelle Prefetture d'Egitto-Etiopia e dell'Alto Egitto - Etiopia affidate ai Frati Minori (1630-1792), „Studia Orientalia Christiana Collectanea”, 10/1958, s. 50-52.

Mayer H. E., The Crusades, Oxford $1988^{2}$.

Meinardus O.F. A., Christians in Egypt: Orthodox, Catholic, and Protestant Communities Past and Present, Cairo 2010.

Meinardus O.F. A., The Capuchin Missionary Efforts in the Coptic Monasteries, „Studia Orientalia Christiana Collectanea”, 20/1987, s. 189-202.

Moskal T., ,...Zastaliśmy w zakrystii Turka w zawoju, z broda ogromna”. Adam Prosper Burzyński OFM (1755-1830) jako prefekt apostolski w Egipcie, w: Kościół w Polsce, Dzieje i kultura, red. J. Walkusz, t. 15, Lublin 2016, s. 71-81.

Mruk W., Czy św. Franciszek z Asyżu odbyt pielgrzymkę do Jerozolimy?, „Peregrinus Cracoviensis”, 22/2011, s. 117-124.

Mruk W., Działalność franciszkanów w Ziemi Świętej w XIII wieku, w: Krucjata bez krucjat. Ofranciszkanach na ziemiach islamu, red. A. Zając, Kraków 2011, s. 81-113. 
Myszor W., Koptyjski Kościót, w: Encyklopedia Katolicka, t. 9, red. A. Szostek et al., Lublin 2002, kol. 815-823.

Paczkowski M. C., Bracia Mniejsi w Egipcie, „Ziemia Święta”, 99/2019, nr 3, s. 36-39.

Paczkowski M. C., Franciszkanie nad Nilem, „Ziemia Święta”, 100/2019, nr 4, s. 16-19.

Paczkowski M. C., Powstanie i początek Kustodii Ziemi Świętej, „Scriptura Sacra”, 13-14/2009-2010, s. 71-94.

Roncaglia M., St. Francis of Assisi and the Middle East, Cairo $1957^{3}$.

Rossi B., La Custodia di Terra Santa, Jerusalem 1979.

Runciman S., Dzieje wypraw krzyżowych, tłum. J. Schwakopf, Warszawa 1987.

Saletti B., I francescani in Terrasanta (1291-1517), Padova 2016.

Sire H.J. A., Kawalerowie Maltańscy, tłum. H. Szczerkowska, Warszawa 2000.

Somigli T., Montano G. M., Etiopia francescana nei documenti dei secoli XVII e XVIII, t. 1-2, Firenze 1928-1948.

Sourdel J. i D., Cywilizacja islamu, tłum. M. Skuratowicz, W. Dembski, Warszawa 1980.

Swastek J., Damietta, w: Encyklopedia Katolicka, t. 3, red. F. Gryglewicz et al., Lublin 1979, kol. 990.

Szteinke A., Polscy Bracia Mniejsi w służbie Ziemi Świętej 1342-1995, Poznań 1999.

Tuchle H., Bouman A., Historia Kościoła, t. 3: 1500-1715, tłum. J. Piesiewicz, Warszawa 1986.

Van Zeelst L., Franciscans in Egypt, w: The Coptic Encyclopedia, t. 4, red. A.S. Atiya, New York 1991, s. 1121-1124.

Verdon T., San Francesco e la Terrasanta, w: In Terrasanta. Dalla Crociata alla Custodia dei Luoghi Santi, red. M. Piccirillo, Firenze-Milano 2000, s. 139-143.

Wiśniowski A., Kustodia Ziemi Świętej, w: Encyklopedia Katolicka, t. 10, red. W. Granat et al., Lublin 2004, kol. 272-276.

Zaki M. S., Histoire des coptes d'Égypte, Paris 2005.

Źródła Franciszkańskie, oprac. R. Prejs, Z.J. Kijas, Kraków 2005. 